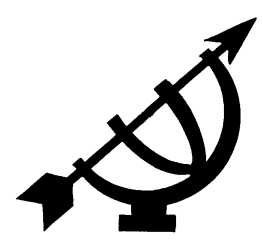

\title{
Biblical counselling regarding inner change
}

\author{
Yvonne Campbell-Lane \& George A. Lotter \\ School of Ecclesiastical Sciences \\ Faculty of Theology \\ Potchefstroom Campus \\ North-West University \\ POTCHEFSTROOM \\ E-mail: campbell@pixie.co.za \\ kwsgal@puk.ac.za
}

\begin{abstract}
Biblical counselling regarding inner change

The concept of inner change is not only the ultimate goal of counselling; it is also a central concept of the gospel. Biblical counselling entails a Scriptural understanding of the nature of change and aims at helping the counsellee change his/her inner life under the guidance of the Holy Spirit. Change is the essence of the process of sanctification, entailing "putting off" (laying off) sinful ways of life, renewing the mind, and "putting on" ("clothing" oneself) with godly ways of life (Eph. 4:22 ff.; Col. 3:8 ff.; Rom. 12:1-2). Although believers have a new identity in Christ, they still suffer from the effect of sin and have to grow in sanctification. Often the believer has not been instructed about changing previous irrational and unbiblical beliefs, behaviour, and habits, and he/she thus still integrates these negative results of sin into his/her new life. Unless old patterns are replaced with new ones, the counsellee can revert to sinful habits, unbiblical beliefs and behavioural patterns. A pastoral counsellor thus needs to teach the counsellee that God has made provision for him/her to change. A worldly anthropology-psychology is entirely opposed to the Biblical doctrines of sin and sanctification. Effective Biblical counselling depends on a Biblical anthropology and world view. A Biblical counsellor should promote holiness and a lifestyle in accordance with Biblical guidelines, thus shaping the counsellee to the likeness of Jesus Christ. When a Biblical counsellor ministers the Word of God in a life-transforming way, then God himself changes the counsellee from the inside out. A counsellor may not ignore sin and its
\end{abstract}


effect as it will limit the effectiveness of counselling in facilitating lasting change in the life of a counsellee. It is important that a Biblical counseller understands the nature of change and is equipped with knowledge about, and the character of change.

\section{Opsomming}

\section{Bybelse berading met betrekking tot innerlike verandering}

Innerlike verandering is nie net die einddoel van berading nie, dit is ook 'n sentrale konsep van die evangelie. Bybelse beradering behels 'n Skriftuurlike insig in die wese van verandering en 'n strewe om hulle wat berading ontvang te help om hulle lewe te verander onder leiding van die Heilige Gees. Verandering is die essensie van die proses van heiligmaking en behels dat die persoon wat berading ontvang sy sondige lewenswyse aflê, sy denke vernuwe en hom/haar sal beklee met die nuwe lewe (Ef. 4:22 e.v.; Kol. 3:8 e.v.; Rom. 12:1-2). Ten spyte van die Christen se nuwe identiteit in Christus, het sy sondige natuur steeds 'n effek op sy lewe en het hy nodig om te groei in heiligmaking. In die meeste gevalle word die gelowige nie onderrig dat sy/haar irrasionele en onbybelse denke, gedrag en gewoontes moet verander word nie. Indien hierdie ou lewenstyl nie vervang word met die nuwe lewe nie, sal hy/sy terugval in die ou sondige gewoontes, onbybelse denke en gedrag. Die pastorale berader moet die persoon wat berading ontvang, leer dat God dit moontlik maak dat hy/sy kan verander. ' $n$ Sekulêre antropologiese en sielkundige siening staan in skerp teenstelling met 'n Skriftuurlike siening van sonde en heiligmaking. Effektiewe Bybelse berading steun op 'n Bybelse antropologie en wêreldbeskouing. 'n Bybelse berader moet heiligheid en 'n Christelike lewenstyl aanmoedig by hom/haar wat berading ontvang sodat die beradene meer en meer soos Christus kan word. As die Christen-berader die Woord van God bedien op 'n wyse wat lewensveranderend werk, bring God die Vader die innerlike verandering teweeg by hulle wat die berading ontvang. 'n Pastorale berader behoort bedag te wees op die effek van sonde in die lewe van die beradene. Om sonde en sy nagevolge te ignoreer kan die effektiwiteit in die fasilitering van verandering in die lewe van die beradene beperk. Dit is noodsaaklik dat die berader die aard van verandering verstaan en toegerus is met kennis oor die aard en die kenmerke van verandering.

\section{Introduction}

Scriptural perspectives (Eph. 4:22 ff.; Col. 3:8 ff.; Rom. 12:1-2) on change do exist and could be used as a foundation and a frame of reference in Biblical counselling. These Scriptural perspectives exhort the believer to "put off" his/her former nature, renew the mind, and "put on" a new nature. 
The aim of this article is to explore Biblical counselling with regard to inner change in the life of the counsellee. It is therefore necessary to explore and understand the uniqueness and distinctive aspects of pastoral counselling pertaining to change. These aspects will be discussed relating to inter alia the pastoral counsellor, different perspectives on Biblical counselling, different worldviews and postmodernity. Other aspects that will be discussed include the following: beliefs in line with Biblical guidelines and beliefs not in accordance with Biblical guidelines, brain-mind issues, perspectives regarding inner change, inner change in line with Biblical guidelines and the process of inner change.

In defining Biblical counselling it is imperative to indicate some parameters on what is meant by the term counselling. The uniqueness of Biblical counselling is distinctly set forth by Meier et al. (1991:292):

- The Bible is accepted as final authority in the counselling process.

- The indwelling power of the Holy Spirit is depended on.

- Biblical counselling deals effectively with the counsellee's past by working with forgiveness and guilt.

- Biblical counselling is based on God's love.

- It deals with the person in its totality and takes cognisance of physical, psychological and spiritual aspects of human beings.

For Ganz $(1993: 56,57)$ a point of departure for this kind of counselling is that an individual should become aware of his true nature. Only then is he able to acknowledge his sin-filled nature that needs a restored relationship with God through Christ. Coe (1999:112) indicates that there can be no Christian plan for change apart from submission to Scripture. Biblical counselling goes beyond the alleviation of problems and personality change only.

According to Crabb (1988:32) most people cope with life by rearranging what they do. If a believer ignores that which is happening in the inner person, he or she will be unable to effectively change what is happening to his/her overt behaviour. The inner Biblical change and spiritual growth the believer strives for, is not only effected through dehabituation, but also entails rehabituation, while focusing on what God demands in His Word. This aim can only be achieved and sustained through the work of the Holy Spirit (Adams, 1994:103). 


\section{The uniqueness of Biblical counselling}

Biblical counselling refers to a process of encouraging spiritual growth and inner change. Because God is a covenant-keeping God, Adams (1979:177 ff.) explains, He is dependable and instils hope in the counsellee. God provides the believer with the necessary resources, directions and the power for the change He commands (2 Pet. 1:3). Biblical counsellors aspire for more than mere renewal and know that the effects of grace are far greater than the effects of sin on the human person. In the words of the apostle Paul according to Romans 8:37: “... we are more than conquerers through him who loved us".

A Biblical anthropology and worldview are of great importance to the Biblical counsellor. According to Crabb (1987:71ff.), the counsellor can only understand and communicate what he knows in a way that will change the life of the counsellee, if he uses Scriptural concepts as his frame of reference. Collins (1995:172) stresses that Biblical counsellors should use Jesus Christ as the ultimate example of a counsellor. With compassion a counsellor should take in position next to the counsellee in order to help him. A counsellor should continually strive to increase in Scriptural knowledge, and grow in sanctification. Primarily grounded in Biblical principles, he should also be skilled in the use of techniques that can help the counsellee move towards change and spiritual growth, directing his focus on Christ. His work should not depend upon his own abilities, training, and counselling skills, but should be exercised under the direction and guidance of the Holy Spirit.

\section{Different perspectives in Biblical counselling}

MacArthur and Mack (1994:44) are of the opinion that in the 19th and 20th centuries the church lost its pastoral skill. In the 20th century the practice of counselling became infused with secular perspectives of understanding and helping people. Johnson and Jones (2000:12) regard the issue of psychology and Christianity as being on a continuum: the non-religious perspective at the one end of the continuum and at the other, the viewpoint of "Fundamentalistic Christians", who accept only Biblical perspectives.

According to Atkinson and Field (1995:82 ff.) the Christian response to this rise from secular psychology can be regarded in terms of five positions in pastoral counselling: 
- Assimilative position - in the early years of the 20th century, pastoral counsellors increasingly relied on scientific psychology for insight. Academic psychology, influenced by William James, increasingly focused on Christianity, giving rise to the discipline of the psychology of religion. Hiltner has been an important figure in this regard.

- Eclectic position - borrows from different sources, adopting the relevant approach to meet the counsellee's particular need, e.g. Clinebell's views.

- Excluding position - some Christian counsellors have adopted a theological position, rejecting the value of psychological insight (Worthington, 1993:32). The special revelation of God through the created order is emphasised (e.g. Adams' nouthetic counselling).

- Perspectivalist position - theology and psychology are regarded as two valid disciplines that bring complementary understandings to human nature. While both disciplines are respected, any overlapping between them is rejected.

- Integrational position - according to Faw (1995:15 ff.) there is an attempt to bring together psychology and theology into specifically Christian methodologies, regarding "all truth (moral, propositional or ontological) as God's truth".

- Integrationalist position - Gary Collins and Bruce Narramore are exponents of this position. McMinn $(1996: 26,258)$ regards it as necessary to understand the relationship between psychology and theology and how Christian faith can be used practically in counselling. Knowledge of different disciplines can only contribute to the effectiveness of the counselling process.

Meier et al. (1991:313) maintain that in spite of their oneness in Christ and their belief in the Bible, pastoral counsellors still differ in their views of counselling. The following exponents are examples of the main positions held in Biblical counselling and their perspectives on change:

\subsection{Nouthetic counselling}

According to Adams (1986:ix) the word nouthetic is derived from the Greek noun and verb forms, nouthesis and noutheteo (Col. 3:16), indicating that all Christians should teach and confront one another in a nouthetic fashion. Adams (1995:17) regards nouthetic counselling as primarily concerned with behaviour, value, 
motivation, and attitude change at the inner core of the counsellee's being. Counselling should address the heart of human difficulty man as a sinner looks to God to give him a new life, with new goals, and purposes. The counsellor is not mainly concerned with how people can be changed, but rather asks the question, "Into what?" The nouthetic counsellor reply to the mentioned question will be: "Into the likeness of Jesus Christ". Adams (1986:61 ff.) argues that the Word of God is the standard for what the counsellee must become and also indicates how to become it. The Bible contains answers to the problems experienced in life, but these answers are only available to the believer who is in a proper relationship with God. There are four elements that are interrelated in the process of change: the work of the Holy Spirit, the counsellor, the counsellee and the Bible.

From another angle Lotter (2001:325) summarises the points of criticism against Adams as "biblisism, behaviourism and 'nothing buttery"'. He argues that these points of criticism should be taken seriously as it indicates the one-sidedness of Adams' nouthetic counselling as he ignores the findings of psychological research.

\subsection{Theophostic ministry}

Smith's method of Theophostic ministry (Smith, 2000:5 ff.) can be applied when a counsellee demonstrates the prevalence of lies from childhood wounds that are embedded in the memory. Through Theophostic ministry the counsellee can experience the truth of Jesus Christ, bringing healing to him. The two terms Theos (God) and phos (light) describe the way God brings forth illumination into a previously darkened area of the mind. Theophostic ministry is God's true Light, Jesus Christ through the Holy Spirit, bringing divine truth into the life experiences of the counsellee. The emotionally hurted counsellee experiences healing as truth replaces lies and thus truth frees him from emotional/psychological pain. These "lies" that are replaced by truth include misinterpretations or unbiblical beliefs rooted in the memory, as well as lies that may be right at the surface or buried so deep that they have been forgotten

Zuehlke (2000:261) explains that thoughts and beliefs about life events create emotions, and emotions trigger certain behaviour. He states that "When the thoughts are based on lies that were believed during traumatic events, the feelings are heavy and the behaviour maladaptive". Britton (2002) has found that during these sessions in which emotional hurt surfaces the counsellee and counsellor often experience the Father's heart in a very special way. They delve 
deep to expose the roots, allowing the counsellee to receive God's healing. This kind of ministry takes the legal ground away from the enemy to steal, kill and destroy (John 10:10). Smith (2000:12) believes that "when you heal the past, you redeem the present".

The points of criticism raised on Theophostic ministry in an article of the Community Church (2001) include the following: Theophostic ministry does ill justice to the sufficiency claimed by Scripture. A superficial view of sin is displayed, promoting a lie-based theology. Furthermore Theophostic ministry has a distorted understanding of the doctrine of man and has similarities with Roman Catholic theology concerning imputation and impartation. It presents an unscriptural view of effort in the Christian life. It is argued that Smith (2000) creates the notion of no self-effort in the healing process.

\subsection{Larry Crabb's integrative model}

Crabb (1987:21) argues that psychological disorders are a product of a sinful pursuit of life apart from God. The counsellee needs to understand and be affected by the truth of the Bible. The following three assumptions govern Crabb's thinking:

- The Bible is sufficient to provide a framework for counsellors.

- A relationship with Christ provides resources in resolving every psychological problem.

- The community of God's people functioning together in Biblical relationship is the intended context for understanding and implementing God's answers to life's problems.

Principles and ideas that are derived from psychology, according to Crabb (1987:28 ff.), must remain consistent with Biblical teaching. He maintains that "where the Bible speaks, it speaks with authority, where it does not speak, counsellors must look to other sources of information to help". Crabb concludes that real change has occurred if the counsellee finds joy in God and becomes involved with others in an improved relationship.

In his book Inside out Crabb (1988:42 ff.) stresses that sanctification is regarded as inner work with outward consequences. In another publication, Connecting, Crabb (1997:5 ff.) emphasises that the fellowship into which the counsellee has entered with Christ should be of such a nature that it will spill over to other people with the power to change their lives. Crabb's definition of connecting is: "Something that occurs when the life of Christ in one person is poured into another and awakens in the emptiest recesses of that 
person's soul the experience of life." Connecting thus occurs when the existence of Christ in one individual touches the existence of Christ in another individual.

In an article, "Psychoheresy" (2001) Crabb's method is commented on and as point of criticism described as "presenting a psychologized substitute for sanctification, sounding very biblical". To add psychological theories and techniques to Biblical data reveals an insufficient confidence in Scripture. The article labels integrationists as "defending their dual faith in Scripture and psychology".

\subsection{Gary Collins's "Christian counselling"}

According to Collins, an integrationist, the Bible is not to be regarded as a textbook on counselling (Collins, 1993:38). He accepts that all truth is God's truth that must always be consistent with, and tested against the norm of revealed Biblical truth. Collins (1988:39) maintains that Jesus desires an abundant life on earth and eternal life in heaven for believers. Christian counsellors should have the same desires and goals for their counsellees. The individual who is not experiencing this abundant life on earth needs counselling.

Specific counselling goals will depend largely on the counsellee's problems, but any list is likely to include at least the following: Selfunderstanding, communication, learning and behaviour change, selfactualisation (preferable Christ-actualisation), support and spiritual wholeness. According to Collins (1995:5) the counselling process must not be regarded as a step-by-step process, as each counsellee is unique with unique problems, attitudes, values and expectations. Collins regards counselling as consistent with terms like encouragement, meeting needs, reaching out, or giving support, without disregarding the techniques of psychology or other helping professions. Christian helping must also entail the Great commission to make disciples of all nations.

MacArthur and Mack's (1994:67) comment on Collins's approach is that he is one of the most significant and seminal individuals attempting to produce an integrative construct. Collins focuses on the worldview and presuppositions that prevail in secular psychology; he attempts to displace or amend those with elements of a thoroughly Christian worldview, thus redeeming the discipline from its own destructive foundation.

The worldview that the counsellor holds, greatly influences counselling techniques, because his counselling perspective derives 
from that worldview. It is therefore important to know how a counsellor regards man and his world.

\section{The effect of an underlying worldview in counselling}

The term worldview encompasses man's life in its totality. It does not represent the real world, but gives direction to the individual in his understanding of the world and his life in it. Murphy (1996) gives the following definition: "A worldview is a set of presuppositions (or assumptions), which is held (consciously or unconsciously) about the basic make-up of the individual's world". A worldview provides the individual with his basic assumption about his reality, and religion provides him with the specific content of this reality.

McMinn (1996:16) warns that a Christian counsellor should review the underlying worldview of theoretical techniques and the implication it brings into Biblical counselling. According to Ganz (1993:44) the progressive loss of Christian consciousness has immersed theoretical techniques deeper into relativism and irrationalism (not just the upsurge and proliferation of occult and New Age philosophies and practices). Boice (1993:73 ff.) asserts that secular comes closest to what Paul actually refers to as the pattern (course) of this world (Eph. 2.2). Secularism disregards the eternal and thinks only of the "now". This attitude implies that there is no need to be concerned about God, sin, judgment or salvation.

Deist (1984:117) lists the following "-isms" underlying certain worldviews: Humanism is a philosophy that tends to exalt human existence with a disregard of God. The relativist's belief is that because everything is in a constant process of change, truth, goodness and beauty do not exist. Materialism regards matter as the only basic constituent of the universe. Everything, including the human mind, emanates from matter. Boice (1993:81) asserts that Christians should attempt to be transformed into the image of the Lord Jesus, rather than be forced into the mould of this world's sinful "-isms".

Anderson et al. (2000:32) name New Age as the fastest growing philosophy/religion in America, disregarding the need for a Redeemer. Instead, the individual only needs enlightenment. Resolving health problems is a question of mind over matter. New Age uses meditation to focus on the "god within". An aspect stressed by Heitink (1999:40) is that a society needs a worldview, because it is an integral and inspiring idea in which life and action are rooted. As a society develops, traditional religion sometimes 
gradually disappears and ceases to fulfil this role. Although science has to a large extent replaced traditional religion, the need for a worldview remains - a worldview that will give meaning to life and answers to existential questions. Stott (1992:57) refers to two key words in the first part of Romans 12:2. The first key word is world, which means age (aiôn, meaning this present age). The second word (do not) conform, is a compound, having at its root the word for scheme. In actual fact, this verse means do not let the age in which you live force you into its scheme of thinking and behaving.

Until the mid 1990s, according to Powlison (1999:2), counselling problems seemed to be caused by painful experiences of being used or abused by others. Unhealthy relationships were regarded as the cause of unpleasant emotions with a sense of woundedness. The dysfunctional family was seen as the reason for bad childhood experiences that needed healing and help. The hurted inner self, with its tragic experiences, faded and the focus shifted to the discovery that genes, hormones and the brain cause problems. The body, and not the family, was regarded as dysfunctional. The Human Genome Project blamed the genetic underpinnings for common sins. Brain chemistry and genetics thus became the significant cause of personality problems. The view was held that appropriate drugs could be administered to solve the problems of the dysfunctional body. In the mid 1990s the focus moved to the body with the emphasis on brain functions. Pawlison gives the following account of this situation:

Recently, biological psychology is the only plausible claimant (besides Biblical faith) to a Grand Unified Theory of human functioning. It was idiocy to say that everyone was a victim of abuse. It is too unpleasant to admit sin against God ...

Van der Walt (1994:100-106) expounds on four positions held represented in Christian worldviews:

- Gratia contra naturam (grace against nature): the Christian should reject worldly aspects such as science, politics and philosophy.

- Gratia supra naturam (grace above nature): because grace completes creation, it cannot inherently change nature.

- Gratia juxta naturam (grace alongside nature): redemption and nature are equally valid but without any connection.

- Gratia in naturam (grace penetrating into nature): grace (redemption) is able to change creation. Grace is not situated 
against, above or alongside nature, but penetrates into nature, renewing and transforming from the inside out. This approach aims to serve God in His world.

\section{Biblical/unbiblical beliefs}

Kylstra and Kylstra (2001:157) assert that the individual's belief system includes Biblical and unbiblical beliefs. Unbiblical beliefs can be described as: "All beliefs, decisions, attitudes, agreements, judgments, expectations, vows, and oaths that do not agree with God (His Word, His nature, His character)"; Biblical beliefs imply "All beliefs, decisions, attitudes, agreements, judgments, expectations, vows, and oaths that do agree with God (His Word, His nature, His character)". The question could then be rightly asked if all Biblical beliefs agree with God, why are there so many deviant views and positions within the sphere of Biblical beliefs?

Hilton and Hilton (2002) indicate that the individual is prone to form ungodly beliefs as he experiences life's circumstances. The hurts and lies the individual experienced during his formative years with his parents (teachers and peers) will greatly influence his view of what the world is like. The results of unbiblical beliefs, according to Kylstra and Kylstra (2001:164), affect the way the individual perceives himself, how he relates to others and to God and determine the quality of his Christian life. Unbiblical beliefs are by definition, "unbelief" that could hinder faith in God and the truth of His promises. "For as he thinketh in his heart so is he ..." (Prov. 23:7). According to Astern (2002), the way to handle these unbiblical beliefs is to renounce them and then to change them into godly beliefs based on the Word of God.

\section{The brain-mind issue, brain processes and Biblical counselling}

Knowledge of brain-mind issues and brain processes is important to this article, because renewal of the mind is an aspect of inner change and knowledge of this kind can contribute to the field of Biblical counselling. Ashbrook (1996:141 ff.) postulates that: "Knowledge of the brain contributes to counselling because it relates the objective knowledge of neuro-cognitive processes with the subjective knowledge of experiential awareness." He maintains that "[b]ecause the mind is the significance of the brain and God is the significance of the mind, the concept 'mind' bridges how the brain works in traditional patterns of belief". The concept mind has linked 
the human significance of the brain and theological concepts that humans have developed in speaking about God.

Faw (1995:28) contends that the brain has always been a focal point for psychologists because it exerts a strong influence on human behaviour and mental life. The brain is able to respond to events in the environment on the basis of information stores it has built up over an individual's lifetime. The problem concerning mind-body is how to hold together the obvious characteristics of an individual and his overt behaviour and the characteristics of his internal mental state. It is expressed as the tension between the material and the immaterial, between brain and mind, between body and soul.

Dell (1993:218) explains that the left and right hemispheres process information differently with different functional specialisations. He addresses the continuum from science to theological reflection, moving from physiology, psychology to the implication of contemplation for theology and faith formation. He explains further that "mind" and "brain" are two views of the same reality - mind implies how the brain experiences its own functioning, and brain provides the structure of the mind. For Neetling and Rutherford (2001:55) both hemispheres of the brain need to be considered in the process of counselling with regard to information processing. The right-brain is dominant in the expression and experience of emotions and is responsible for "remembering" and recalling these experiences.

\section{Perspectives regarding inner change from a Scriptural view}

The following aspects stress the uniqueness of Biblical counselling and the different counselling perspectives pertaining to inner change as goal of all Biblical counsellors.

\section{- The reality of sin}

Spykman (1992:312) explains that man is sinful (Rom. 3:23), and all pain in this world is caused by the occurence of sin in the life of the believer. The effect of sin must be dealt with in order for healing to occur. For Prutow (1997) it is important to realise that although sin remains, it does not have mastery over the believer (Rom. 6:8).

\section{- The doctrine of justification and sanctification}

McGee (1997:243) asserts that justification is an act of God, declaring the believer to be righteous and placed in right standing before God (Rom. 3:23 ff.). God's will for the believer is his 
sanctification. Harrison (1987:364) explains that spiritual change and growth in the life of the counsellee should be a habitual endeavour that is brought about by the ministry of the Word of God (2 Tim. 3:15 ff.).

\section{- Establishing and breaking habits}

Macquarrie and Childress (1986:258) stress the importance of habit in everyday life, where learning is made possible, reducing the time and effort necessary for repeated activities. Individuality is reflected by habits because it includes characteristic patterns of thinking, speaking and responses. According to Adams (1994:101) habits can be regarded as a blessing from God. The opposite is also true: a habit can be turned into a curse where all kinds of sinful responses become part of the individual. Adams (1979:161) points out that wrong habits cause barriers to spiritual growth in the Christian's life, making change very difficult. Prutow (1997) indicates that habits are unconscious responses that are difficult to change. The counsellor thus needs to direct the counsellee to become conscious of his unconscious responses. As the ruling power of sin is broken (Rom. $6: 5 \mathrm{ff}$.) in the life of the believer, bad habits can now be left behind and new ones can be formed through disciplined living by the power of the Holy Spirit.

\section{- Dehabituation/Rehabituation}

Guzik (2001) contends that Christians cannot be comfortable with habitual sin. Paul challenges believers to "put off" the old nature in every area of life, calling him/her to a deeper obedience (Eph. 4:22). Cash (2002) explains that when an individual attempts to stop a habit (dehabituate), a vacuum is created. If believers are not encouraged to fill that void, it will most often be filled with the old habit again. According to Adams (1973:177; 1979:239) dehabituation cannot be permanent without rehabituation, and rehabituation will be temporary, unless it has been preceded by dehabituation. God not only calls Christians to a holy life (1 Pet. 1:16), but also provides the ways and means to godliness. Godly life patterns are developed and acquired through the obedient practice of spiritual disciplines (Bruce, 1984:357).

\section{- Renewing the mind}

The process of inner change will not be complete without renewing the mind. This process signifies that the counsellee should be reprogrammed through the Word of God and by the power of the Holy Spirit to prevent him from reverting to old habit patterns. On the other hand, Satan is determined to keep the believer's mind 
unrenewed through establishing a fortress of deception with negative thoughts contrary to the Bible (Kylstra \& Kylstra, 2001:70). The mind needs to be renewed so that Satan's lies can be replaced with God's truth. If an individual's thoughts are contrary to Scripture, he should do what Paul teaches in Philippians 4:8.

\section{Agencies to equip the believer}

God has provided the following agencies for believers to become better equipped for their Christian life style (Crabb, 1987:135):

\section{- The Holy Spirit}

The counsellee can only change by the power of the Holy Spirit in him. Effort apart from the Holy Spirit cannot produce inner change any apparent change will be superficial or temporary. Collins (1993:153) reminds that if translated Paraclete (the name of the Holy Spirit), means comforter, helper, advocate, or counsellor. Because the Christian is the temple of the Holy Spirit (1 Cor. 6:19), He guides and transforms the believer from the inside out.

\section{- The Word of God}

Renewing the mind will ultimately bring about change in the life of the counsellee in proportion to his understanding of the Biblical truth that applies to his situation (Kylstra \& Kylstra, 2001:75). According to Crabb (1987:129) Scripture should dominate the thinking processes of the counsellee (Col. 3:16). Changing the thought processes in a way that is in harmony with the Biblical guidelines will lead to positive change in every aspect of life.

\section{- The church}

According to Roberts (1991:142) the inner renewal of a life that stems from a relationship with God is often lacking among so many members. The crisis in the church is that it cannot say to those whose names are recorded in the church registers: "You have indeed come to know God, so relinquish the old way of life, live the new life by being renewed in your deepest spiritual being." The church is largely to blame because it has accepted members as a mere fashion without truly instructing them about those things that constitute the Christian faith.

\section{- The counsellor}

The counsellor, equipped with Biblical truth, can offer the counsellee objective guidance and steps for renewing his mind and to facilitate change. The Christian counsellor should instruct counsellees to 
become aware of and be committed to Biblical norms (Crabb, 1987:129). According to MacArthur and Mack (1994:144) counsellors should pray that their own lifes will be examples of obedience to Biblical principles and constant growth in the knowledge of the Bible.

\section{- Being in Christ}

According to Galatians 2:20 God inhabits the believer's spirit. The believer is in Christ, and Christ is in him by the Spirit of God. Coe (1999:117) illustrates this condition by means of the following questions and answers: "Who am I? I am now 'Christ in me'. There is still me, but in time and with growth, I can come to observe and experience another within who informs me of my real identity of being in the Beloved". MacArthur and Mack (1994:119) maintain that to speak of change also involves speaking of being in Christ, which includes the past, present and future of a believer's transformation. Being in Christ includes the Christological blessings of justification, new life, and the indwelling of the Holy Spirit. Anderson et al. (2000:89) argue that from the moment the believer has put on the new nature, Christ is in him/her and it is important for every believer to know what it means to be in Christ. The Christian's position and identity in Christ is not just positional truth, but is the basis for living and growing in Christ.

\section{Specific aspects pertaining to pastoral counselling methods}

\section{- Emotions and the way of thinking}

Emotions and thinking, as elements of the mind, are very important aspects in pastoral counselling. According to Louw (2000:166) pneuma (spirit - the inner dimension and awareness) can be regarded as the centre of a Christian's understanding or personality which labels the person as an individual and conscious being who is dependent on God. Kierkegaard (cf. Coe, 1999:111) comes to the conclusion that "[t]rue understanding of human personality and human happiness is realized only when the person is grounded in the Source of Being: that is, indwelt by, and in union with, God by the Holy Spirit". For Coe the concept of the New Covenant is central to the Christian understanding and experience of self. Being in Christ and Christ in the believer are two fundamental and complementary aspects of self in relation to the New Covenant reality. This indwelling ministry of the Holy Spirit penetrates to the very core of the human personality. 
Emotions and the way of thinking are important aspects in pastoral counselling because counselling is concerned with healing hurted and damaged emotions. Because thought processes determine behaviour, these processes should be considered in facilitating change. Tice (1990:1) argues that the individual does not react in accordance to the truth, but rather to what he perceives to be the truth. The individual's potential is limited by the way he thinks. If thinking processes can be changed (renewed), behaviour can also be changed. According to Louw (2000:198) the affective dimension plays an important role in personality and "can be described as the porthole, which gives insight into the inner experience of the human soul or I". Counselling, according to Crabb (1977:89), can be thought of as "an effort to teach the counsellee 'correct thinking', to choose 'correct behaviours' and then to experience 'right feelings'”.

\section{- Whole-brain counselling}

The counsellor needs to take note of the basic facts of the functioning of the brain as it impacts on learning and counselling. To enable the counsellee to change, certain principles, Biblical truths and Scripture portions should be studied. In these tasks the Christian counsellor should act as a facilitator.

Hopper (1992) indicates that both hemispheres are involved in almost every human activity. According to Stone (2002) most individuals give preference to the left hemisphere, which functions analytically and logically in a sequential order. When concrete facts are taught this process has a short-term impact. Blakelee (1980:28) asserts that the right hemisphere can be regarded as the centre of intuition, imagination and creativity. When facts with extended associations are processed the right-brain experiences them emotionally and the information can then easily be recalled with lasting effect (Neetling, 2000:57).

\section{- Left-brain-right-brain learning styles}

Hopper (1992) explains that the individual should know how he should process information optimally in order to master presented material more efficiently. The learning process is enhanced when all senses are used. The counsellor should also take note of these facts to assist counsellees in acquiring new behavioural patterns.

\section{- Whole-brain counselling}

Clinebell (1987:27) suggests that right-brain methods should be used for healing and growth in counselling. Janse van Rensburg 
(1998:65) maintains that pastoral counselling has primarily made use of left-brain methods. There is, however, a need to integrate right-brain methods with left-brain analytical approaches. Spiritual disciplines such as prayer, meditation and imaging are experiential resources for spiritual growth. In the New Testament Jesus Christ also appealed to the creative side of the individual, by explaining certain life issues by applying parables and metaphors. Williams (1983:58) maintains that using metaphors enables the individual to connect to new concepts of prior knowledge and experiences, allowing him to internalise new knowledge.

\section{Inner change in line with Biblical guidelines}

According to Johnston (2001), the response to the question "What is change?" should be the answer "becoming more like Christ". A Christian should present himself as an instrument of obedience to God, and not to sin. Adams (1986:14) is of the opinion that there should be a distinction between godly righteous change and an individual's self-righteous change. A pastoral counsellor should minister the Word of God in a life-transforming way, trusting the Holy Spirit to change the counsellee from the inside out. This is a gradual process, requiring the dehabituation of old habitual sin and rehabituating new, righteous Biblical acts. Growing during the different life-cycles requires constant change. It is therefore important for Christians to learn how to handle change.

The question, "What are you trying to change?" thus also comes to mind. Landrum (2002) indicates that any desirable Biblical change should primarily be grounded in a person's vertical relationship with Christ and his horizontal relationships with other people, as well as with his environment. These relationships will naturally result in the second phase of Biblical change that takes place concurrently with the first, that is, putting off the old man, renewing the mind, and putting on the new man (Eph. 4:22 ff.).

\section{- The dynamics of change}

Fowler (1988:99 ff.) expresses the following view on change: "Echoing Saint Paul we can say that we have been changed, we are being changed and will be changed." Fowler identifies three types of change with which the individual must deal. These types and sources of change interact with one another, so that change begun in one area of experience, may precipitate change in another. Making distinctions between these kinds and sources of change can be helpful: developmental change (maturation), reconstructive 
change (entails a response of some experience or failure in love or work), and change as a response to intrusive marker events (e.g. divorce, death, retirement, unemployment). The latter kind of change is brought about by disruptive events, affecting life patterns pervasively.

\section{- Hindrances to inner change}

MacArthur and Mack (1994:242, 243) explain that the first hindrance to inner change occurs when a believer does not understand the way Biblical change comes about. He might expect God to supernaturally take away his problems, not realising that selfdiscipline plays a very important role in sanctification. A second hindrance is when the counsellee's motive for change is not directed towards pleasing and glorifying God with his life. The lack of commitment is a third hindrance. Because inner change is a choice and does not come about by chance, the counsellee needs to commit to accomplish change (Prov. 14:23). Listed in the last place is either the unwillingness to make a change or not knowing how to make the changes God requires of him.

\section{- Implementing change in a Biblical sense}

Lifestyles and patterns set by habits may become a part of one's behaviour to the extent that this behaviour does not act in accordance to Biblical guidelines - they are performed with ease and often unconsciously. After dehabituation, old patterns most often emerge again. MacArthur and Mack (1994:294) suggest that change in a Biblical sense should be implemented in such a way that change will become permanent. New patterns of response must become dominant by habitually turning to them when experiencing life stress. The counsellee needs encouragement to change, and to be reminded that with perseverance a desired activity will eventually become a part of him.

Meier et al. (1991:317) maintain that change in a Biblical sense can be implemented by formulating a list of alternatives and a plan of action to problem areas in the counsellee's life. In the course of reaching goals and solving problems, feelings will change. Emotions and feelings could constitute a faulty belief system from the past according to which the counsellee may still be acting. As the believer meditates on the Word of God and applies it to his life, his belief systems and feelings will change (James 1:22).

Part of implementing change in a Biblical sense is going beyond talk and proceeding to action. Inducement is essential to help the 
counsellee make decisions and commitments conducive to change and in line with a Biblical lifestyle. These acts of change should become a lifestyle of a lifetime decision. When discouraged, the counsellee needs to be reminded again who he is in Christ and to look upon himself as God sees him: now perfect and risen, having acquired a new life in Christ Jesus. The changed mind must be defended against thoughts, attitudes and behaviour that once controlled the counsellee - the old ways will not automatically fall away. Every time the counsellee defends his mind against the old way of thinking, he strengthens the new way (Treat, 1999:195). Adams (1979:265) explains that change in a Biblical sense sometimes calls for "radical amputation", implying that the counsellee must anticipate temptation, and then try to prevent it by avoiding temptation. Treat (1999:198) stresses the important role of the church as a support base. Every believer is part of the body of Christ (1 Cor. 12:12 ff.) depending on it to have needs met.

\section{Aspects of inner change}

Buchanan (1966:3) explains that after the individual has been born again, the necessity of great spiritual change exists in him, followed by a progressive course of sanctification:

The soul is the subject of this change; it is not an external reform merely, but an internal and spiritual renovation, a change of mind and heart, taking effect on the understanding ... when 'he is transformed by the renewing of the mind' and 'created anew in Christ Jesus unto good works'; so he is said to be 'a new creature, in whom old things have passed away, all things have become new'.

Change is brought about by the Word of God, the instrument through which the Holy Spirit acts (Möller, 1997:152).

\section{- The Holy Spirit and change}

According to Heim (1997:5) the Holy Spirit will not only enable the believer in the activities of "put off, renew and put on" (Eph. 4:22 ff.), but will also produce a certain kind of result in the life of the believer: restraining the flesh, renewing the mind and revealing Christ through his example and ministry to others. According to Adams (1986:44) the Holy Spirit operates through the Bible to change lives. The following functions of Scripture is said to be performed in conjunction with the Holy Spirit: 
- Teaching the principles necessary for immediate and lasting change (1 John 2:27).

- Conviction of sin (John 16:7-11).

- Correction (Gal. 6:1): the Bible and the power of the Holy Spirit together supply the necessary help for change and to forsake any sinful attitude or behaviour.

\section{- Christian spirituality}

Spirituality describes the life of grace of living in fellowship with God. Ferguson et al. (1988:657) are of the opinion that in Christian terms the word spirituality is best used to mean "living as a Christian". Spirituality is not just the "spiritual part" of man, but includes the life of the whole person. There are essentials in spirituality, which are the same for all Christians, both in the aim (being conformed to the likeness of Jesus Christ - Rom. 8:29) and in the means (the spiritual disciplines). Spirituality is not a mere technique to be mastered, but is a response of total dependence of creature before his Creator, God Almighty. According to Foshaugen (1999:14) to live a spiritual life does not entail applying a list of external things or refraining from doing it. True spirituality comprises of practising a Christian life, lived moment by moment.

\section{- The practice of spiritual disciplines}

God not only commands change, $\mathrm{He}$ also provides the ways and means to godly living through the practice of spiritual disciplines. The Christian life should be oriented towards godliness and the way to achieve it is by means of discipline (1 Tit. 4:7). Foster and Yanni (1992:21) assert that the purpose of spiritual disciplines entails the total transformation of a human being. The aim of these disciplines should be to replace old destructive habits of thought with new lifegiving habits. Willard (1988:67) describes spiritual disciplines as follows:

The disciplines are activities of mind and body purposefully undertaken, to bring our personality and total being into effective co-operation with the divine order. They enable us more and more to live in a power that is, strictly speaking, beyond us, deriving from the spiritual realm itself, as we yielded ourselves to God, as instruments of righteousness unto God', as Romans 6:13 puts it.

The habitual practices of the Lord Jesus form the core of those very activities that through the centuries have stood as disciplines of the spiritual life. It seems only right that the believer would imitate Christ's daily actions, since He was the Master of spiritual life. 
Atkinson and Field (1995:310) regard spiritual disciplines not as acts of penance to pay for the soul's misdoings. Spiritual disciplines imply the believer's desire or hungering after God (Ps. 42:1) to assist him in acquiring deeper change. Whitney (1991:15 ff.) lists three primary means of changing the believer to be more Christlike: people (e.g. pastors and counsellors), circumstances (hardships in life as growth experiences - 2 Cor.1, and spiritual disciplines (change comes through the practice of spiritual disciplines). Whitney stresses that spiritual disciplines are not effective in themselves but that they only put the believer in a position where God is best able to change willing human beings, that is, from the inside out. The mentioned disciplines are God's means of grace where He can work in the believer to bring about change and maturation (Phil. 2:12 ff.).

Foster (1998:xii, 6) categorises spiritual disciplines as follows:

- Inward disciplines: meditation, prayer, fasting, and articles of faith (something you feel very strongly about so that it affects how you think or behave).

- Outward disciplines: simplicity, solitude, submission and service.

- Corporate disciplines: confession, worship, guidance and celebration.

God has given spiritual disciplines to the believer to place himself before God in order to be transformed by God and to be in a position where God can bless him.

\section{Conclusion}

The essence of this article is the important fact that a characteristic of a life in accordance with Christian guidelines is that such a lifestyle is not static - it implies a life-long process of change. The believer can therefore not continue in everyday life with his or her old ways of life. Because of inner renewal, a believer should be leading a new life. Change is the essence of the process of sanctification, entailing putting off sinful ways of life, renewing the mind, and putting on godly ways of life. This is a difficult process because it is not easy to say "no" to the self (dehabituate) and "yes" to Jesus Christ (rehabituate). A Christian should live a life consistent with that to which God has called him and that reflects a life modelled by Jesus Christ. In his day-by-day way of living a Christian should become what he already is in Christ. These aspects contribute to the understanding of the connection between inner change and Biblical counselling. 


\section{List of references}

ADAMS, J.E. 1973. The Christian counsellor's manual: the practice of nouthetic counselling. Grand Rapids: Zondervan.

ADAMS, J.E. 1979. A theology of Christian counselling: More than redemption. Grand Rapids: Zondervan.

ADAMS, J.E. 1986. How to help people change: The four-step Biblical process. Grand Rapids: Zondervan.

ADAMS, J.E. 1994. The Christian counsellor's commentary: Galatians, Ephesians, Colossians, Philemon. Hackettstown: Timeless Text.

ADAMS, J.E. 1995. Change them? ... Into what? The Journal of Biblical Counselling, 13(2):13-17, Winter.

ANDERSON, N.T., ZUEHLKE, T.E. \& ZUEHLKE, J.S. 2000. Christ-centered therapy: The practical integration of theology and psychology. Grand Rapids: Zonndervan.

ASHBROOK, J.B. 1996. Brain processes and pastoral counselling. The Journal of Pastoral Care, 50(2):141-150, Summer.

ASTERN, D. 2002. Ungodly beliefs. http://www.destinyspirit.com/drc.html [15 Dec. 2002].

ATKINSON, D.J. \& FIELD, D.H. 1995. New dictionary of Christian ethics and pastoral theology. Leicester: InterVarsity.

BLAKELEE, T.R. 1980. The right brain: A new understanding of the unconscious mind and its creative powers. Garden City: Anchor.

BOICE, J.M. 1993. Renewing your mind in a mindless age: Learning to think and act Biblically. Grand Rapids: Kregel Publications.

BRITTON, B. 2002. Ungodly beliefs. http://www.scriptureforamerica.org/htm12/ jm0077d.htm [18 Aug. 2002].

BRUCE, F.F. 1984. The epistles to the Colossians, to Philemon, and to the Ephesians. Grand Rapids: Eerdmans.

BUCHANAN, J. 1966. The Holy Spirit. London: Bookprint.

CASH, T. 2002. Put off, put on. http://www.mercyseat.com/put.htm [5 Nov. 2002].

CLINEBELL, H. 1987. Basic types of pastoral care and counselling. Nashville: Abingdon.

COE, J.H. 1999. Beyond relationality to union: Musing towards a pneumadynamic approach to personality and psychopathology. Journal of Psychology and Christianity, 18(2):109-128, Summer.

COLLINS, G.R. 1988. Christian counselling: A comprehensive guide. Revised ed. Grand Rapids: Zondervan.

COLLINS, G.R. 1993. The Biblical basis of Christian counselling for people helpers. Colorado Springs: Navpress.

COLLINS, G.R. 1995. How to be a people helper. Wheaton: Tyndale House.

COMMUNITY CHURCH. 2001. Biblical evaluation of Theophostic ministry. http://www.communitychurch.19520.org/theophostic.htm [3 July 2002].

CRABB, L. 1977. Effective Biblical counselling: A model for helping caring Christians become capable counsellors. Grand Rapids: Zondervan.

CRABB, L. 1987. Understanding people. London: Marshall Pickering.

CRABB, L. 1988. Inside out. Colorado: Navpress.

CRABB, L. 1997. Connecting. A radical new vision. Nashville: Word Publishing.

DEIST, F. 1984. A concise dictionary of theological and related terms. Pretoria: Van Schaik. 
DELL, M.L. 1993. Brain, symbol and experience: A psychiatric and theological dialogue. Journal of Religion and Science, 28(2):217-230, June.

FAW, H.W. 1995. Psychology in Christian perspective. An analysis of key issues. Grand Rapids: Baker Book House.

FERGUSON, S.B., WRIGHT, D.F. \& PACKER, J.I. 1988. New dictionary of theology. Downers Grove: InterVarsity.

FOSHAUGEN, E.K. 1999. An incarnational engaged worship and spirituality. Acta Theologica, 19(2):14-31, Dec.

FOSTER, R.J. 1998. Celebration of discipline: The path to spiritual growth. New York: Harper Collins.

FOSTER, R.J. \& YANNI, K.A. 1992. Celebrating the disciplines: A journal workbook. New York: Harper Collins.

FOWLER, J.W. 1988. Faith development and pastoral care. Philadelphia: Fortress.

GANZ, R. 1993. Psychobabble: The failure of modern psychology and the Biblical alternative. Wheaton: Crossway Books.

GUZIC, D. 2001. Colossians 3 - Put off, put on. http://www.enduringword.com [5 Nov. 2002].

HARRISON, R.K. 1987. Encyclopedia of Biblical and Christian ethics. Nashville: Thomas Nelson.

HEIM, J. 1997. Christlikeness: Committing ourselves to be changed by God. Colorado Springs: NavPress.

HEITINK, G. 1999. Practical Theology: History, theory, action domains. Cambridge: Eerdmans.

HILTON, S. \& HILTON, M. 2002. Un-godly beliefs/Godly beliefs. http://www. givinglight.org/prophh.htm [15 Dec. 2002].

HOPPER, C. 1992. Biblical discernment ministries: Learning styles. http://www.hyponoetics.org/ [31 March 2003].

JANSE VAN RENSBURG, J. 1998. Regterbrein-strategieë vir pastorale terapie. Nederduitse Gereformeerde Teologiese Tydskrif, 39(1 \& 2):65-78, Maart \& Junie.

JOHNSON, E.L. \& JONES, S.L. 2000. A history of Christians in psychology. (In Johnson, E.L. \& Jones, S.L., eds. Psychology and Christianity. Downers Grove: InterVarsity. p. 11-53.)

KYLSTRA, C. \& KYLSTRA, B. 2001. Restoring the foundation: An integrated approach to healing ministry. 2nd ed. Santa Rosa Beach: Proclaiming His Word Publications.

LANDRUM, T. 2002. Biblical sanctification. http://www.Topical/landrum_ss/ Change\%20Part\%206.htm [2 Aug. 2002].

LOTTER, G.A. 2001. The "reformation" of counselling. In die Skriflig, 35(2):317329.

LOUW, D.J. 2000. A pastoral hermeneutics of care and encounter: $A$ theological design for a basic theory, anthropology, method and therapy. Wellington: Lux Verbi.

MacARTHUR, J.F. \& MACK, W.A. 1994. Introduction to Biblical counselling: A basic guide to the principles and practice of counselling. Dallas: Word Publishing.

MacQUARRIE, J. \& CHILDRESS, J. 1986. A new dictionary of Christian ethics. London: Liturgical Press.

McGEE, R.S. 1997. The search for significance. 2nd ed. Houston: Rapha. 
McMINN, M.R. 1996. Psychology, theology and spirituality in Christian counselling. Wheaton: Tyndale House.

MEIER, P.D., MINIRTH, F.B., WICHERN, F.B. \& RATCLIFFf, D.E. 1991. Introduction to psychology and counselling: Christian perspectives and applications. 2nd ed. Turnbrige Wells: Monarch.

MÖLLER, F.P. 1997. The work of the Holy Spirit in the life of the believers. Pretoria: Van Schaik.

MURPHY, E. 1996. The handbook for spiritual warfare. Nashville: Thomas Nelson. (Nelson's electronic Bible reference library.) [CD-ROM.]

NEETLING, K. 2000. Think like Jesus. Vanderbijlpark: Carpe Diem Books.

NEETLING, K. \& RUTHERFORD, R. 2001. Creative people can perform miracles. Vanderbijlpark: Carpe Diem Books.

NEWMAN, B. 2002. Taking the gospel to a postmodern world. http://www.skybusiness.com/billnewman/index52.html [6 Aug. 2002].

POWLISON, D. 1999. X-ray questions: Drawing out the whys and wherefores of human behaviour. The Journal of Biblical Counselling, 18(1):2-9, Fall.

PRUTOW, D. 1997. Dehabituate: in response - although sin remains. http://www.sterlingpulpit.org/Adobe-Newsletters/july-1997.pfd [5 Nov. 2002].

PSYCHOHERESY. 2001. Has Larry Crabb changed? http://www.psychoheresyaware.org/crabbchanged.html [5 July 2002].

ROBERTS, J.H. 1991. The letter to the Ephesians. Goodwood: Lux Verbi.

SMITH, M. 2000. Beyond tolerable recovery. Campbellville: Alathia.

SPYKMAN, G.J. 1992. Reformational theology: A new paradigm for doing dogmatics. Grand Rapids: Eerdmans.

STONE, H.W. 2002. Left-brain right-brain. http://www.righthandlefthand.com/ pdf/NOTES [5 July 2002].

STOTT, J.R.W. 1992. The contemporary Christian: Applying God's Word to today's world. Illinois: InterVarsity.

TICE, L. 1990. Investment in excellence. Seattle: The Pacific Institute.

TREAT, C. 1999. Renewing the mind. Tulsa: Harrison House.

VAN DER WALT, B.J. 1994. The liberating message: A Christian worldview for Africa. Potchefstroom: The Institute for Reformational Studies.

WHITNEY, D.S. 1991. Spiritual disciplines for the Christian life. Colorado Springs NavPress.

WILLARD, D. 1988. The Spirit of the disciplines: Understanding how God changes lives. London: Hodder \& Stoughton.

WILLIAMS, L.V. 1983. Teaching for the two-sided mind. New York: Simon \& Schuster.

WILSON, R. 2001. Christianity and today's culture. http://www.decaturedaily. com/decaturedaily/books/011104/book3.shtml [6 Aug. 2002].

WORTHINGTON, E.L. 1993. Psychotherapy and religious values. Grand Rapids: Baker Book House.

ZUEHLKE, J.S. 2000. Theophostics. (In Anderson, N.T., Zuehlke, T.E. \& Zuehlke, J.S., eds. Christ centered therapy: The practical integration of theology and psychology. Grand Rapids: Zondervan. p. 262-266.) 
Key concepts:

Biblical counselling: nature of; characteristics

change: nature and dynamics of

counselling methods

new identity in Christ

\section{Kernwoorde:}

beradingsmetodes

Bybelse berading: die aard van; kenmerke

nuwe identiteit in Christus

verandering: aard en dinamika van 
